\title{
THE POLITICAL AND DIPLOMATIC RELATIONS BETWEEN LITHUANIA AND ROMANIA (1935-1940)
}

\section{Dalia Bukelevičiūtè}

Vilnius University, Faculty of History, E-mail: fl_anghel@yahoo.com

This paper has been presented at the First International Conference on Nordic and Baltic Studies in Romania: Romania and Lithuania in the Interwar International Relations: Bonds, Intersections and Encounters hosted by the Romanian Association for Baltic and Nordic Studies, Târgoviste, May 19-21, 2010.

\begin{abstract}
:
The first contacts between Lithuanian and Romanian representatives started after the World War I when Lithuania was looking for the protection of her inhabitants who were still refugees in Russia. As Russia became entrenched with Bolshevism, the Lithuanian citizens were evacuated through Romanian territory from South Ukraine and Crimea. Lithuania and Czechoslovakia established diplomatic relations in December 1919 and eventually an attempt was made to set up ties also with Romania. As a member of the Little Entente and an ally of Poland, Romania drew the attention of the Lithuanian government. Romania recognized Lithuania de jure on August 21, 1924 and Dovas Zaunius was appointed the first Lithuanian envoy to Bucharest. Nevertheless, during the next decade no political or diplomatic contacts between Lithuania and Romania existed. With the growing influence of Germany, the Soviet Union and the Little Entente on the international arena, Edvardas Turauskas was appointed on August 27, 1935 as envoy to Romania residing in Prague and later in the year Romania accredited ConstantinValimarescu for the position of envoy to Lithuania residing in Riga. The dialogue between the two parties remained, however, occasional. When on July 21, 1940 Lithuania was occupied by Soviet Union, Turauskas visited the Romanian Legation in Bern and presented a note of protest in this respect. Romania did not acknowledge Lithuanian occupation and annexation.
\end{abstract}

\section{Rezumat:}

Primele contacte dintre reprezentanți ai Lituaniei şi ai României au început după Primul Război Mondial atunci când Lituania avea în vedere protejarea cetățenilor săi refugiați în Rusia. In vreme ce în Rusia bolşevicii preluau puterea, lituanienii erau evacuați pe teritoriul românesc din Ucraina sudică şi Crimeea. In noiembrie 1919 Lituania a solicitat oficial guvernului român dreptul de tranzit şi în toamna anului 1920 primul-ministru român Averescu i-a promis asistență 
The political and diplomatic relations between Lithuania and Romania (1935-1940)

reprezentantului lituanian Lisauskas. Praga a fost $\hat{\imath}$ perioada interbelică un centru important pentru diplomația lituaniană în ceea ce priveşte inițierea legăturilor cu România. Lituania şi Cehoslovacia au stabilit relații diplomatice în decembrie 1919. In martie 1920 Donatas Malinauskas a fost desemnat însărcinat cu afaceri în capitala Cehoslovaciei, iar Ministerul Afacerilor Externe al țării sale i-a solicitat să obțină recunoaşterea de jure din partea României. Guvernul lituanian era interesat în stabilirea unor relații apropiate cu România deoarece această țară era membră a Micii Antante. Guvernul lituanian era de asemenea interesat în relațiile României cu Polonia, cu atât mai mult cu cât conflictul lituaniano-polonez era cea mai importantă chestiune de politică externă lituaniană. Din nefericire, Malinauskas nu a progresat în încercarea de a înnoda dialogul dintre cele două ministere de externe. Lituania a arătat un interes mult mai mare în ceea ce priveşte România după ce Dovas Zaunius a fost numit ministru plenipotentiar în Cehoslovacia în 1923. România a recunoscut Lituania de jure la 21 august 1924 atunci când relațile diplomatice dintre cele două state au fost stabilite. În aceeaşi lună Zaunius a vizitat Bucureştii şi în noiembrie a fost numit în calitate de ministru plenipotențiar al Lituaniei în România cu reşedința la Praga (până la 11 februarie 1925). România şi-a exprimat intenția de a desemna un ministru în Lituania cu reşedința la Varşovia, dar Lituania nu a fost de acord nici atunci, nici în 1927. In perioada 1925-1927 contactele politice şi diplomatice dintre cele două state au lipsit. Ministerul Afacerilor Externe al Lituaniei a fost interesat în desemnarea unui ministru lituanian la Bucureşti în 1933, dar paşi concreți în această direcție au fost făcuți abia în anul 1935 in circumstanțe diferite marcate de creşterea influenței Germaniei, Uniunii Sovietice şi a Micii Antante pe scena internațională. La 27 august 1935 Edvardas Turauskas a fost numit ministru al Lituaniei în România cu reşedința la Praga (până la ocupația sovietică a Lituaniei). Turauskas a vizitat Bucureştii, l-a întâlnit pe regele României, miniştrii afacerilor străine, diplomați şi i s-a solicitat să întreprindă o vizită în România în fiecare an. La sfârşitul anului 1935, România l-a numit pe Constantin Vallimarescu în calitate de ministru în Lituania cu reşedința la Riga. In martie 1939, după ce Praga a fost ocupată de Germania nazistă, Turauskas s-a întors în Lituania, menținându-şi însă poziția de ministru plenipotențiar în România. In Lituania acesta a stabilit contacte $\mathrm{cu}$ diplomatii români. In anul viitor diplomații lituanieni şi cei români au întreținut contacte la Berna, Paris, Londra şi în alte capitale. La 21 iulie 1940 Lituania a fost ocupată de Uniunea Sovietică, iar diplomați şi reprezentanți lituanieni au decis să prezinte note de protest împotriva actului ilegal al ocupației. Turauskas s-a stabilit la Berna la 4 iulie 1940, iar la 25 iulie a vizitat Legația României pentru a prezenta o asemenea notă de protest. Acesta a fost ultimul contact al lui Turauskas cu reprezentanții României în calitatea sa de ministru în România. România nu a recunoscut anexarea Lituaniei.

Keywords: Romania, Lithuania, Prague, diplomatic relations, 1930s, Little Entente, Baltic Entente

At the end of the First World War, Lithuania has gained its independence. In spite of this achievement, the young Lithuanian state still 
had some unresolved disputes regarding Vilnius' and Klaipeda's regions statute. These political issues somewhat limited Lithuania's international standing when the government was seeking for international and diplomatic de jure recognition from the European community, especially as the disputes opposed it to some of the neighboring countries, such as Poland, Russia and Germany. For that reason, it was especially important for the Lithuanian state to achieve political and diplomatic cooperation with other European countries. The main objective was however to search for diplomatic relations with large countries. Lithuania's special interest in Balkan countries seems to have appeared slightly later. There is no mention of political ties between Lithuania and Romania in the Lithuanian historical literature, which is similar to the situation of Lithuanian foreign affairs with the rest of the Balkan countries. This article is based only on the analysis of the historical archive documents, which are not included into Lithuanian historiography spectrum as yet.

The first diplomatic contacts between Lithuania and Romania started around the fall of 1918. These ties were based on Lithuania's primary concern over the issue of bringing home the Lithuanian political refugees and prisoners of war. The Lithuanian government issued a statement to their representatives in Prague to seek for diplomatic relations with other countries and to gain their de jure recognition. The Romanian Foreign Ministry did not show much interest in such encounters with the Lithuanian state. Eventually, in 1923, an active Lithuanian politician D. Zaunius showed initiative and made the first diplomatic steps towards the Romanian side. He got in touch with the Romania's envoy extraordinary and minister plenipotentiary, D. Hiot. Zaunius described him the situation in all of the Baltic States. In the summer of 1923, the Lithuanian and Romanian diplomatic contacts became more active and from here resulted Romania's recognition of Lithuania's independence on August 21, 1924. Although Romania recognized Lithuania de jure and de facto, the two countries did not exchange diplomatic representatives.

Only eleven years later, the two countries strengthened up their political relations. There were many reasons for this positive change in the relations between them, especially the fact that the political situation in Europe had changed by then. As regards the bilateral relation, E. Turauskas, the Lithuanian envoy extraordinary and minister plenipotentiary, was appointed in Prague on October 25, 1934 and subsequently he showed much initiative in contacting the Romanian diplomats in Prague. At the same time, the Romanian legation in Riga gathered some useful information about Lithuania. The Romanian diplomats eventually sent all this information to Bucharest. 
According to the documents from the archives, the Lithuanian side was first to propose diplomatic representatives to the Balkan countries. Lithuania wanted to have equally good foreign diplomatic relations with Romania and Yugoslavia. Lithuanian and Romanian representatives agreed on the start of diplomatic relations between the two countries in spring till autumn of 1935. Thus, Turauskas became Lithuanian envoy extraordinary and minister plenipotentiary in Romania since August 27, 1935 and in Yugoslavia from November 15, 1935. From autumn 1935 until spring 1936, the Lithuanian diplomats have actively searched a man who can be appointed as Lithuania's honorable consul to Romania, but these searches finished without results.

Every year E. Turauskas would visit Bucharest where he would meet influential Romanian politicians. The first visit took place in November 1935. On November 29, he submitted his credentials to the King of Romania. Turauskas was unpleasantly surprised that during this ceremony, the Romanian side did not play the national anthem of Lithuania and King Charles II did not reflect on some of the essential subjects presented by the Lithuanian politician. Turauskas called their brief discussion as "the most banal possible". 1

At the end of 1935, the Lithuanian state issued a diplomatic agreement to the Romanian envoy extraordinary and minister plenipotentiary, C. Vallimarescu, who however resided in Riga, not in Kaunas. This fact was disappointing to Lithuanian politicians. Vasile Stoica, the new Romanian envoy extraordinary and minister plenipotentiary in Lithuania and Latvia, was appointed on March 9, 1937.2

When the year 1936 started, all the members of Little Entente and Baltic Entente fully normalized their diplomatic contacts. From a geopolitical perspective, the political ties between the Little Entente and the Baltic Entente started a new era of political cooperation between the two alliances. As already mentioned, the previous year Romania set up diplomatic relations with the Baltic countries by appointing an envoy extraordinary and minister plenipotentiary to Riga and Tallinn. Lithuania, on other hand, started international bonds with the Little Entente countries and appointed Turauskas as Lithuanian diplomatic representative to these countries residing in Prague. This way, Prague became a very important

\footnotetext{
1 Lithuanian envoy extraordinary and minister plenipotentiary in Czechoslovakia E. Turauskas' report of 14.12.1935 from Prague to the Ministry of Foreign Affaires of Lithuania, Lithuanian Central State Archive (hereafter, LCVA). F. 648. Ap.1.B. 14.L.334.

${ }^{2}$ Czechoslovakia's envoy to Lithuania J. Skalickýs report of 15.03.1937 from Kaunas to the Ministry of Foreign Affaires of Czechoslovakia, Archive of Ministry of Foreign Affaires of Czech Republic (hereafter, AMZV). Pz-Kaunas 1937, č.j. 87-duv.
} 
The political and diplomatic relations between Lithuania and Romania (1935-1940)

political center for the formation of the geopolitical dimension of Lithuania's foreign policy. In the years 1936-1937, Kaunas was looking for more intensive political contacts with the Balkan countries especially considering the fact that Italy and Germany showed more interest in the Balkans. Consequently, Lithuania entered into diplomatic relations with the Hungary.

The Foreign Minister of Czechoslovakia K. Krofta became an important source of political information to Lithuania as regards the Romanian political matters. In June 1936, Turauskas and Krofta discussed about Romanian King Charles the Second's visit to Prague and some other important subjects such as the possibility of a Romania's agreement with the USSR. They also approached the growing USSR's political influence in Romania. Krofta confirmed the information that the Romanian King mentioned the possible freezing of political ties between Czechoslovakia and the USSR. The Romanian monarch also approached the political relations between Czechoslovakia, Romania and the USSR.

The changing political ties between Romania and Poland aroused the Lithuanian interest. When the Romanian Minister of Foreign Affairs V. Antonescu visited Warsaw, the Lithuanian state officials kept a close eye on this event. The Lithuanians were wondering how this would affect their foreign relations with Romania and Poland. ${ }^{3}$ Turauskas also hoped to find out during his second visit in Bucharest more about the visit of the Polish Foreign Minister Colonel Beck to Romania of May 1937. Antonescu confessed him that Romania was simply renewing an old agreement between the two countries. He reassured the Lithuanian representative that the Romanian-Polish agreement was not set against any other country in particular. ${ }^{4}$

During his second visit in Bucharest just as in 1935, Turauskas encountered some difficulties in scheduling a meeting with the Romanian Foreign Minister. The meeting was, however, a fiasco and Turauskas described it in such words as: "The talk was unpleasant and the interlocutor wanted as much as possible to finish it". 5

During this short interview, Antonescu appreciated that Romania's relations with the USSR were good enough. Cădere, Romania's envoy in Prague, gave more information to Turauskas regarding the RomanianSoviet relations. He mentioned that the changes on the Balkan political

\footnotetext{
${ }^{3}$ J. Skalický report of 05.02.1937 from Kaunas to Foreign Ministry of Czechoslovakia, AMZV, Pz-Kaunas 1937, č.j. 43-duv.

${ }^{4}$ E. Turauskas report of 18.05.1937 from Prague to Foreign Ministry of Lithuania, LCVA. F. 648. Ap.1.B.16.L.64.
}

5 Ibid., L.63. 
The political and diplomatic relations between Lithuania and Romania (1935-1940)

arena were mainly influenced by the Soviets and argued that Titulescu would sign a military agreement with the USSR only if M. Litvinov would cease being so stubborn about Besarabia. ${ }^{6}$

In the fall of 1937, the Lithuanian diplomatic community showed interest in the issue of national minorities. Romania did not agree to sign a resolution concerning the Hungarian minority as other Little Entente countries did. The government in Kaunas implied that the real reason of Romanians was as much rotten in their domestic politic arena as in Titulesco's personality who wanted to make stronger his opposition. S. Lozoraitis, the Minister of Foreign Affairs of Lithuania met with Krofta in Geneva who confessed him that the Romanian side' standing in this issue created unnecessary tensions within the Little Entente. ${ }^{7}$

In the spring of 1938, the political tensions in Europe grew high and Kaunas received information about the matters in the Balkan region from many of the Lithuanian diplomatic legations in the European capital cities. At the time, Turauskas enjoyed good contacts with the Romanian envoy in Prague, T. Emandi. Emandi, showed some political initiative and proposed to President E. Beneš to host periodically so-called "conferences" of Baltic, Little and Balkan Entente groups, but this remained just an idea. ${ }^{8}$ In the meantime, the Lithuanian government lacked the interest to continue sponsoring Turauskas' visits to Bucharest. ${ }^{9}$

By March 1939 the situation in Europe had changed: Germany had occupied the Czechoslovakian state and created a Bohemian-Moravian Protectorate. The Germans had also annexed Klaipeda region from Lithuania. The international relations between Romania and Lithuania was also affected by these changes on the international arena. The Lithuanian legation in Prague closed down in June 1939 and Prague ceased to be the center of political dialogue between the two states. After Czechoslovakia's occupation, Turauskas left Prague and returned to Kaunas not being posted as diplomat in Romania. A new page in the history of RomanianLithuanian relations was thus opened.

In September 1939 the Second World War started. This tragic event tied up both Romania and Lithuania close to each other. Both countries

\footnotetext{
${ }^{6}$ E. Turauskas report of 04.05.1937 from Prague to Foreign Ministry of Lithuania, LCVA, F. 648. Ap.1.B.16. L.55.

${ }^{7}$ Memorandum of Foreign Minister of Lithuania of 26.10.1937, LCVA, F. 648, Ap.1. B.53. L. 110.

${ }^{8}$ E. Turauskas' report of 03.03.1938 from Prague to Foreign Ministry of Lithuania, LCVA. F. 648, Ap.1. B.14. L. 125-126.

${ }^{9}$ E. Turauskas' report of 03.03.1938 from Prague to Foreign Ministry of Lithuania, LCVA, F. 383. Ap. 7. B. 2035. L. 28.
} 
The political and diplomatic relations between Lithuania and Romania (1935-1940)

continued their political dialogue in the capitals of third states. Amongst subjects of those dialogues were the political issues and the problems they faced at the start of the conflagration such as the Romanian relations with Germany or Soviet Union and their possible retaliations during the war. Romania openly showed interest in the Vilnius' region matters and in the spectrum of relations between Lithuania and Poland.

By the middle of September, the Romanian envoy extraordinary and minister plenipotentiary Cruțescu visited the Lithuanian minister K. Škirpa in Poland and informed him that the Romanian government officially announced its neutrality in the war. The Romanian diplomat was interested, as Škirpa reported, "if we were going to regain Vilnius". Škirpa answered that the Lithuanian government was holding its ground firmly on neutrality on this particular matter and that he didn't have the authority to discuss this issue. Crutescu implied that "the mentioned region is de facto without government so that it wouldn't clash with neutrality to invade it and that possibility it wouldn't be any risks" in doing so. Škirpa answered that it was Poland who had to show its initiative towards Lithuania "for all of the harm they did", but Poland never stepped up with a possible truce. Crutescu also wanted to know about the general population's opinion in this matter and Škirpa informed him that the Lithuanians wanted Vilnius back but this was not the political course and position of the Lithuanian government. ${ }^{10}$

In the same month, the Romanian envoy to Paris, R. Franasovici, showed his concerns over the Baltic and Balkan countries' future fate. He was interested also in Vilnius' region problem (he had worked in Warsaw before the war) and about the political interests of Moscow. The Lithuanian envoy P. Klimas assured Franassovici that such an early return of Estonian Minister Setler's delegation could be due to serious reasons. Besides, the Romanian diplomat mentioned "the possible Bolshevik propaganda that can cause serious consequences inside the countries".11

A few weeks later, Klimas visited Franasovici in Paris in order to gain some additional information about Romania's relations with and USSR. The Romanian diplomat informed him that the Soviet ambassador in Bucharest stated that Russia "doesn't have anything against Romania and the only Russian concerns are about status quo in the Black Sea region". In

\footnotetext{
${ }^{10}$ Lithuanian envoy in Poland K. Škirpa's secret report of 15.09.1939 to Foreign Ministry of Lithuania, LCVA. F. 648. B. 40. L. 82-83.

11 Lithuanian envoy in France's secret report of 26.09.1939 to Lithuanian Foreign Minister J. Urbšys, LCVA, F. 648. B. 30. L. 186.
} 
The political and diplomatic relations between Lithuania and Romania (1935-1940)

Klimas' opinion „Russia would not touch the Bessarabian question if Romania would not join any alliances directed against the Soviet State". ${ }^{12}$

In the beginning of 1940, the Romanian charge d'Affairs in Riga, Gr. Niculescu-Buzeşti was especially satisfied with the fact that the Soviets were being stuck in the war with Finland, which made them less interested in the Balkans for the moment. He informed the Lithuanian diplomats that the Romanian representatives met in Moscow with V. Molotov, but they didn't get any clear and valuable answers on the Soviet view of Bessarabia. After the meeting it was stated that "the Romanian government concludes that the Soviets won't touch upon the Romanian country", but the situation will depend on the evolutions in the war. ${ }^{13}$ The Lithuanian newspapers began to write numerous articles about the situation in Romania at that time.

In February 1940, the Lithuanian Foreign Minister J. Urbšys showed his interest in the Romanian situation. He arranged a meeting in Kaunas with the Romanian Charge d'Affairs, Niculescu-Buzeşti. The latter mentioned him that "nothing had changed" in relations between Romania and Germany. All of the economical treatises between both countries were valid. ${ }^{14}$ Niculescu-Buzeşti also talked to Turauskas about Romania's desire to be neutral in the war and the reasons why some big countries would criticise Romania for that. He stated that Romania, just as the rest of Balkan countries, didn't want the Germans to win the war. But there was a big difference between wishes and the harsh reality. That was the reason for which Romania supplied Germany with their oil.15

In April 1940, the Kaunas Foreign Ministry received an important information regarding situation in Romania from the Lithuanian diplomats in Berlin. They reported that there information circulated from many sources in Europe about the German plans to invade Romania. The Lithuanian diplomat informed that "there is something going to happen in Balkans", but Yugoslavia and Romania tried to avoid confrontation with the Germans and with the Allies, although the pressure coming form both side was high. ${ }^{16}$ More often information from now on was received by Kaunas from the Lithuanian Military Attaché in France, J. Lanskoronskis.

\footnotetext{
12 Lithuanian envoy in France's secret report of 04.10.1939 to Lithuanian Foreign Minister J. Urbšys, LCVA, F. 648. B. 30. L. 195.

${ }^{13}$ Lithuanian envoy in Latvia's secret report of 05.01.1940 to Foreign Minister J. Urbšys, LCVA, F. 648. B. 22. L. 149.

14 Memo of Foreign Minister of Lithuania J. Urbšys of 20.02.1940, LCVA, F. 648. Ap. 1. B. 55. L. 81.

${ }^{15}$ Memo of E. Turauskas of 22.02.1940, LCVA, F. 648. Ap. 1. B. 55. L. 90.

${ }^{16}$ Lithuanian envoy in Germany's secret report of 16.04.1940 to Foreign Ministry of

Lithuania, LCVA, F. 648. Ap. 1. B. 40. L. 279.
} 
All these events culminated in June 1940 when the fate of Lithuania was sealed by the USSR-Germany Pact of Non-Aggression. On the next day, the Red Army crossed the borders of Lithuania. J. Paleckis signed an Act No. 771 on June 19 about the dismissal of Turauskas as Lithuanian envoy extraordinary and minister plenipotentiary in Yugoslavia and Romania. ${ }^{17}$ This happened shortly before the assignment of a new government in Lithuania. On July 21, 1940 the People's Parliament voted and decided to include Lithuania into Soviet Union. The Lithuanian political diplomats sent protest notes to many countries they were assigned and accredited to.

On July 25, 1940 Turauskas visited Romanian legation in Bern and gave an official protest note. This was the last visit of Turauskas as a diplomat and his last meeting with Romanian diplomats.

\section{References:}

\section{Archives:}

Lithuanian Central State Archive:

- F. 383. Ap. 3. B. 293.

- F. 383. Ap. 7. B. 2035.

- F. 648. Ap. 1. B. 14.

- F. 648. Ap. 1. B. 16.

- F. 648. B. 22.

- F. 648. B. 30 .

- F. 648. B. 40.

- F. 648, Ap. 1. B. 53.

- F. 648. Ap. 1. B. 55.

Archive of Ministry of Foreign Affaires of Czech Republic:

- Pz-Kaunas 1937, č.j. 87-duv.

- Pz-Kaunas 1937, č.j. 43-duv.

17 Decision of Minister of Foreign Affaires of Lithuania V. Krèvè-Mickevičius no. 221, LCVA. F. 383. Ap. 3. B. 293. L. 307. 
The political and diplomatic relations between Lithuania and Romania (1935-1940) 